Journal of Research in Interprofessional

Practice and

Education

Vol. 1.2

August 2010
Journal of Research in Interprofessional Practice and Education (JRIPE)

Vol. 1.2

(C) 2010

Corresponding author:

Jenny Godley igodley@ucalgary.cai

\section{Interprofessional Relationships in the Field of Obesity: Data from Canada}

\author{
Jenny Godley, PhD \& Shelly Russell-Mayhew, PhD
}

\begin{abstract}
Background: While it is generally acknowledged that an interprofessional approach is necessary to treat and prevent obesity, there have been few empirical studies examining the working relationships of professionals in the obesity field.

Methods: In this article social network analysis is used to examine the working relationships of 111 attendees, representing eleven different health professions, at the first National Obesity Summit in Canada. We assessed the extent of engagement in interprofessional relations across four activities: discussion, gathering information, providing care, and conducting research. We also examined attitudes toward interprofessional practice.

Findings: On average, respondents reported that approximately $75 \%$ of the people they work with are from other professions. Attitudes toward interprofessional practice were generally positive, and did not vary significantly across professions. Interestingly, attitudes were not related to actual interprofessional relations in our sample. In terms of work type, we found that respondents who were engaged in both clinical and research work had the largest networks and had the highest percentage of interprofessional contacts in their discussion and research networks.

Conclusions: Overall, the results suggest that within our sample of professionals working in the field of obesity, interprofessional practice is held in high regard as a concept. The results also suggest that members of professions that combine both research and clinical work are most likely to engage in interprofessional relationships. This article illustrates the utility of social network analysis to assess the extent of interprofessional relationships among those working in a particular healthcare field.
\end{abstract}

Keywords: Interprofessional practice; Obesity; Social networks; Attitudes

\section{Introduction}

Over the past several decades, researchers in the health sciences have increasingly emphasized the need for interprofessional practice in healthcare $[1,2,3]$. Health policy makers also stress the necessity of providing care using interprofessional healthcare teams, especially in countries where the population is aging, the burden of chronic disease is increasing, and the healthcare system is undergoing financial restructuring $[4,5,6]$. Research has shown that interprofessional teams improve outcomes for patients, especially those with chronic diseases $[7,8]$, and healthcare professionals are now routinely encouraged to work with people from other professions and disciplines, cooperating to provide comprehensive care $[9,10,11]$.

However, it is clear that significant barriers to interprofessional practice remain $[12,13]$. These barriers include disciplinary boundaries, different values, professional self interest, and differential access to resources [14]. Several authors have examined the reinforcement of professional boundaries in the face of requests to engage in interprofessional practice $[15,16]$. Researchers argue that professional centrism and different professional cultures make interprofessional practice difficult to achieve $[17,18]$. 
Interprofessional Relationships: Data from Canada

Godley \& Russell-Mayhew

Journal of Research in Interprofessional Practice and Education

Vol. 1.2

August, 2010
The extent to which interprofessional practice actually occurs in healthcare in Canada is largely unknown. This article uses social network analysis to examine the working relationships of health professionals in the obesity field in Canada. Social network analysis enables us to assess the extent to which individuals from various professions actually work with people from other professions in the field of obesity management and prevention. We then relate these measured working relationships to individuals' attitudes toward interprofessional practice, evaluating whether there is a correlation between attitudes and relationships, and whether this correlation varies by profession. We further examine whether the type of work obesity healthcare professionals engage in (research, clinical, or a mix of the two) is correlated with either their interprofessional relationships or their attitudes.

\section{Background}

Interprofessional education is defined as "occasions where two or more professions learn with, from and about each other to improve collaboration and the quality of care" $[19,20]$. Interprofessional practice is defined as "collaborative practice to enhance patient outcomes" [21] or "health and social care professionals ... work[ing] together effectively to take care of patients effectively" [20]. Research on the working relationships of academics uses the terms interdisciplinary, multidisciplinary, and transdisciplinary to describe academic work that crosses disciplines $[2,22,23]$. For the purposes of this article, we classify both academic and clinical working relationships that cross either disciplinary or professional boundaries as interprofessional relationships $[21,24]$. Individuals in our sample are engaged in research, practice, and a mix of the two: we examine the relationship between an individual's work type and both interprofessional relationships and attitudes toward interprofessional practice.

Much of the literature on interprofessional practice appears in The Journal of Interprofessional Care, which was founded in 1992. There are three main areas of research in the existing literature on interprofessional practice. One group of researchers focuses on evaluating interprofessional teams of healthcare workers, examining how their working relationships function across professional boundaries. A second group of researchers looks at the design and evaluation of interprofessional education in healthcare. And a third group of researchers examines healthcare professionals' attitudes toward interprofessional practice. We briefly describe these three strands of research below.

The literature evaluating the interprofessional practices of teams of healthcare workers tends to focus on programs that were explicitly set up to encourage interprofessional interaction. There have been evaluations of interprofessional teams in many areas of healthcare, including: programs to alleviate social exclusion [25]; child and youth residential care [26]; adult mental health [27]; stroke care [28]; optometry [29]; hospitals [15]; and primary care [30]. Most of this research has found that although healthcare workers in these settings generally support the idea of collaboration, interprofessional work is difficult in practice. Conflict occurs due to different cultures within the professions and differential access to power and resources [31,32]. 
Interprofessional Relationships: Data from Canada

Godley \& Russell-Mayhew

Journal of Research in Interprofessional Practice and Education

Vol. 1.2

August, 2010

\section{Journal of Research in Interprofessional Practice and Education}

Following the calls for increased interprofessional collaboration within the national healthcare systems, there have been attempts at providing interprofessional education during professional training in England, Australia, and Canada. There is some literature evaluating this training [18,33,34]. This research found that although interprofessional education is complex and difficult to evaluate [35], it appears that there are benefits to healthcare workers training with professionals outside their own disciplines $[5,36]$ that translate into better patient care. Recently, authors have been suggesting that patients should also be involved in interprofessional education $[37,38]$.

Thannhauser, Russell-Mayhew, and Scott [39] recently conducted a review of the literature on instruments that measure attitudes toward interprofessional practice outside an existing healthcare team. They examined 23 instruments that have been developed to measure these attitudes broadly, concluding that the most reliable scales are the "Readiness of Health Care Students for Interprofessional Learning Scale" (RIPLS), developed by Parsell and Bligh [40], and the "Interdisciplinary Education Perception Scale" (IEPS), developed by Luecht, Madsen, Taugher and Petterson [41]. Research using these scales has found that healthcare professionals generally have positive attitudes toward interprofessional practice, but that they perceive actual interprofessional practice levels in their fields to be low. Other researchers have also found that healthcare workers are largely optimistic about the benefits of interprofessional practice, but are unsure about implementing it in their own work $[13,42]$.

Missing from the literature on interprofessional practice is an examination of the actual working relationships of people in different professions who are not explicitly formed into interprofessional teams and who practice in different institutional settings. This article uses social network analysis to examine the working relationships of professionals in the field of obesity in Canada.

\section{Social network analysis}

Social network analysis, a research tradition originating in cognitive psychology and anthropology in the 1930s and 1940s, emphasizes the study of relationships rather than the study of individuals' attributes [43]. Sociologists using social network analysis have demonstrated the impact of the relationships between people on diverse outcomes, including health behaviour, attitudinal change, and adoption of innovations [44]. Network analysts typically conduct one of two types of relational analyses: whole network studies, where the boundaries of the population are known and information is gathered from the whole population; or ego-centred network studies, where individuals are asked to report on others with whom they have certain relationships (referred to as the ego's "alters" in network terminology) and the characteristics of their alters [45].

We conducted an ego-centred network study of professionals working in the field of obesity and their working relationships with other professionals. We examined the composition of the individual's networks with respect to profession and institutional affiliation. We looked for differences in network composition by pro- 
Interprofessional Relationships: Data from Canada

Godley \& Russell-Mayhew

Journal of Research in Interprofessional Practice and Education

Vol. 1.2

August, 2010

\section{Journal of Research in Interprofessional Practice and Education}

fession. We then examined individuals' attitudes toward interprofessional practice and looked at whether network composition was related to these attitudes. This article is unique in that it a) examines the working relationships of a variety of professionals from many different institutions, and b) combines information on attitudes toward interprofessional practice with information on actual working relationships.

The article is organized around four central research questions:

1. To what extent are those working in the field of obesity in Canada engaging in interprofessional relationships? Does involvement in interprofessional relationships vary by profession?

2. What are the attitudes of those working in the field of obesity in Canada with regards to interprofessional practice? Do these attitudes vary by profession?

3. How are attitudes toward interprofessional practice related to selfreported actual interprofessional relationships?

4. Is the type of work an individual does (clinical, research, or a mix of the two) correlated with either the extent of their involvement in interprofessional relationships or their attitudes toward interprofessional practice?

\section{Why obesity?}

Recent data from Canada show the national obesity prevalence to be approximately $23 \%$, and according to Health Canada guidelines an additional $36 \%$ of the adult population is overweight [46]. Obesity has been linked to many other chronic diseases and to premature mortality, causing great concern among healthcare workers and policy makers alike [47]. Obesity is an extremely complex health issue, influenced by physical, psychological, and social factors [48].

Many professionals who work in the field of obesity management and prevention agree that effective obesity prevention and treatment services must adopt an interprofessional approach. Indeed, the most recent Canadian obesity guidelines call for an interdisciplinary approach [49]. There are many different health professionals who should be included in obesity research, treatment, and prevention, including physicians; surgeons; psychiatrists; molecular biologists; epidemiologists; social workers; psychologists; nurses; dietitians; occupational, recreational, and family therapists; public health workers; teachers; and program evaluators. Recently, several clinical programs for the obese have been established that take a specifically interprofessional approach (for example, the Weight Wise Adult Weight Management Clinic in Edmonton, Alberta: ihnttp://_www. ']weightwisise In these programs, patients work with a team of professionals, which may include a doctor, a surgeon, a nurse, a physical therapist, a counsellor, and a dietitian, to lose weight and establish a healthy lifestyle. However, these programs are rare and often have long waitlists [50].

Many professionals working in the obesity field find themselves in more traditional academic or clinical settings, without a specific mandate for interprofessional practice. Nonetheless, previous qualitative research on interprofessional practice in 
92

Interprofessional Relationships: Data from Canada

Godley \& Russell-Mayhew

Journal of Research in Interprofessional Practice and Education

Vol. 1.2

August, 2010 the field of obesity shows that professionals are ready to engage in interprofessional practice in their work [51]. This study allowed us to assess to what extent healthcare professionals working in the obesity field in Canada are engaging in interprofessional relationships, and whether these interprofessional relationships are related to attitudes concerning interprofessional practice.

\section{The Canadian Obesity Network}

The Canadian Obesity Network (CON) was formed in 2006 as a national network of obesity researchers, health professionals, and other stakeholders. The goal of $\mathrm{CON}$ is to reduce the mental, physical, and economic burden of obesity on Canadian society. Professionals working in the field of obesity can join CON and then have access to the website, can contact other members, and can attend work-

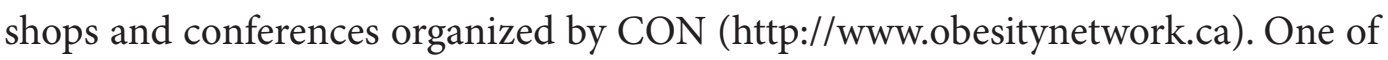
CON's objectives is to provide opportunities for professionals in the obesity field to communicate with each other at national meetings.

The first conference organized by CON was the Western Obesity Summit, held in May 2007. Approximately 110 members of CON from the western provinces attended that summit, where researchers exchanged ideas and information related to their own work in the obesity field. The first National Obesity Summit, organized by CON, was held in May 2009. Approximately 500 people attended this conference, representing different professional groups from all over Canada.

\section{Methods}

Data collection

We collected survey data at CON's National Obesity Summit in 2009. Our sample is a convenience sample of conference attendees. We set up a booth across from the registration tables at the conference, with laptops where people could access the online survey. We also provided people with business cards containing the Web address of the survey. We sent two follow-up emails, one during the Summit and one the week after the Summit, to remind attendees to take the survey. The survey was available on the Web; people could take the survey at any time during the conference or during the two weeks following the conference. All respondents filled out an online informed consent form before they took the survey, and they were guaranteed confidentiality. The study was approved by the Conjoint Faculties Research Ethics Board at the University of Calgary.

We had 111 complete responses, resulting in a response rate of $22 \%$ of all conference attendees. However, it should be noted that our sample is biased in two respects. First, the sample does not represent all those who work in the obesity field in Canada. People attending a National Obesity Summit (where many different professions are represented) may be predisposed to working interprofessionally. Second, the sample does not represent all those who attended the conference. It can be assumed that those who volunteered to take a survey on interprofessional practice may be more interested in it (and may be more likely to view interprofessional relationships as part of their work). 
93

Interprofessional Relationships: Data from Canada

Godley \& Russell-Mayhew

Journal of Research in Interprofessional Practice and Education

Vol. 1.2

August, 2010

\section{Network measures}

We collected ego-centred network data on the working relationships of the respondents. Ego-centred network surveys use "name generators" to prompt individuals to name others with whom they have various relationships. We used the following name generators to ask about the respondents' working relationships: talk with, gather information from, provide care with, and conduct research with. Individuals were able to name up to ten people for each type of relationship [52]. We then asked two questions (referred to by social network analysts as "name interpreters") about each person named: What is this person's profession? What type of organization does this person work for? Using this data, we constructed the following network measures for each type of relationship: network size, percent same profession, and percent same type of institution $[45,53]$.

\section{Attitudinal measures}

As described above, there are several scales that have been used to examine attitudes toward interprofessional practice. For the purposes of this study, we use the Interdisciplinary Education Perception Scale (IEPS) developed by Luecht et al. [41] When the IEPS was first developed, it was content-validated by five faculty in nursing and allied health. In its original usage, with a sample size of 143 (mostly undergraduate students), it was shown to have a composite reliability of .872 [41,54]. The IEPS asks respondents the extent of their agreement with 18 items regarding interprofessional practice (see Appendix A). Ninety respondents completed the attitudinal section of the questionnaire.

\section{Statistical analyses}

We conducted a factor analysis using principal component analysis and varimax rotation to assess the psychometric properties of the IEPS. We retained four component factors with eigen values greater than 1.0, and examined these factors for reliability.

Next, we used analysis of variance (ANOVA) to examine the network size and composition of individuals in the sample by profession. We looked for significant differences between the members of different professions on the following variables: network size, percent same profession, and percent same type of organization. Since we had no a priori hypotheses about differences between the professions on the network variables, we used the least significant difference (LSD) procedure in a post-hoc analysis to examine group differences for all significant ANOVAs.

We then examined the scores on the four attitudinal factors by profession. Again, we used ANOVA to test for significant differences and then conducted a post-hoc analysis using LSD to look at group comparisons for those ANOVAs that were significant.

We next ran a bivariate correlation analysis to examine the correlation between the four attitudinal factors and the network composition measures. We looked at these correlations for the whole sample first and then individually by profession.

After completing the analysis of the network and attitudinal variables by profession, we were interested to see if the type of work individuals engaged in (clinical, research, or a combination of the two) was associated with either relationships or 


\section{JRIPE}

94

Interprofessional Relationships:

Data from Canada

Godley \&

Russell-Mayhew

Journal of Research in Interprofessional Practice and Education

Vol. 1.2

August, 2010
Journal of Research in Interprofessional Practice and Education

attitudes. Thus, we conducted separate analyses of both the network and the attitudinal variables using type of work, instead of profession, as the independent variable. Once again, group means were compared using ANOVA to examine whether the type of work individuals engaged in was related to either the network measures or the attitudinal measures.

Table 1

\section{Sample distribution of profession, institutional affiliation and work type}

\begin{tabular}{|c|c|c|c|}
\hline & & $N$ & Percent \\
\hline \multirow[t]{12}{*}{ Profession } & Academic - Biomedical Sciences & 8 & 7.2 \\
\hline & Academic - Kinesiology & 10 & 9.0 \\
\hline & Academic - Public Health & 16 & 14.4 \\
\hline & Academic - Social Sciences & 8 & 7.2 \\
\hline & Dietitian / Nutritionist & 16 & 14.4 \\
\hline & $\begin{array}{l}\text { Kinesiologist / Physiotherapist / } \\
\text { Occupational Therapist }\end{array}$ & 10 & 9.0 \\
\hline & Psychologist / Psychiatrist & 4 & 3.6 \\
\hline & Medical Doctor & 9 & 8.1 \\
\hline & Nurse & 15 & 13.5 \\
\hline & Public Health Worker & 8 & 7.2 \\
\hline & Administrator & 7 & 6.3 \\
\hline & Total & 111 & 100.00 \\
\hline \multirow[t]{5}{*}{ Institutional Type } & Government / Non profit & 8 & 7.2 \\
\hline & Healthcare & 49 & 44.1 \\
\hline & Private Industry & 6 & 5.4 \\
\hline & University / Research & 48 & 43.2 \\
\hline & Total & 111 & 100.00 \\
\hline \multirow[t]{4}{*}{ Type of Work } & Clinical only & 36 & 33.4 \\
\hline & Research only & 43 & 39.4 \\
\hline & Clinical and research & 30 & 27.5 \\
\hline & Total $*$ & 109 & 100.00 \\
\hline
\end{tabular}

*Note: Total percent is rounded to 100.

\section{Results}

Sample characteristics

Table 1 shows the distribution of professions, institutional affiliations, and type of work for our sample. We had respondents from eleven different professional groups 
JRIPE

95

Interprofessional Relationships: Data from Canada

Godley \& Russell-Mayhew
Journal of Research in Interprofessional Practice and Education

Vol. 1.2

August, 2010 in our sample. The original questionnaire listed 24 professions and an "other" category (see Appendix B). Respondents self-identified as coming from 15 of these professions. We recognize that some of the categories, such as "public health" could include individuals who have very different professional training (for example, a public health nurse versus a public health social worker). However, we are using respondents ' self-identified profession. If a respondent checked "public health," rather than another category, we must assume that they see "public health" as their profession.

To preserve respondent confidentiality, we had to collapse some of the profession categories (for example, psychologists and psychiatrists were placed in one category). In our initial data analysis, we considered "students" as a separate profession. However, we found that the 18 students in our sample were not a cohesive group. Students had networks that were more similar to the networks of (non-student) academics in their own discipline than to students from other disciplines. Therefore, they were re-coded as academics in their respective disciplines.

Most respondents were affiliated with either a healthcare organization (44.1\%) or a university (43.2\%), although a few came from government/non-profit agencies and private industry. In terms of the type of work, the sample was fairly evenly split between those who do only clinical work (33.4\%), those who do only research work (39.4\%), and those who do both (27.5\%).

Table 2

\section{Average network size and composition}

\begin{tabular}{|c|c|c|c|c|}
\hline & Talk to & Gather info. & Provide Care & Research \\
\hline Network Size & $\begin{array}{c}5.87 \\
(2.94)\end{array}$ & $\begin{array}{c}2.14 \\
(2.46)\end{array}$ & $\begin{array}{c}1.76 \\
(2.91)\end{array}$ & $\begin{array}{c}2.13 \\
(3.02)\end{array}$ \\
\hline Percent Same Profession & $\begin{array}{c}30.43 \\
(29.49)\end{array}$ & $\begin{array}{c}27.86 \\
(31.32)\end{array}$ & $\begin{array}{c}23.94 \\
(28.37)\end{array}$ & $\begin{array}{c}30.64 \\
(35.99)\end{array}$ \\
\hline Percent Same Type of Organization & $\begin{array}{c}61.57 \\
(33.53)\end{array}$ & $\begin{array}{c}63.34 \\
(39.69)\end{array}$ & $\begin{array}{c}62.79 \\
(44.36)\end{array}$ & $\begin{array}{c}63.63 \\
(35.42)\end{array}$ \\
\hline$N$ & 108 & 63 & 40 & 50 \\
\hline
\end{tabular}

Cells contain: Mean (Standard Deviation)

\section{Network measures}

The average network size and composition measures for the four types of working relationships are shown in Table 2. First, it is important to note that while all respondents listed people with whom they "talked about obesity-related matters," not all respondents reported gathering information about obesity, providing obesity care, or conducting research on obesity. Thus the sample size changes across the relationship types.

On average, respondents reported talking to 5.87 people about obesity-related matters, gathering information from 2.14 people, providing care with 1.76 people, and conducting research with 2.13 people. Across the four different types of working relationships, respondents reported that approximately $25-33 \%$ of the individuals they nominated were from the same profession as the respondent. This percentage 
96

Interprofessional Relationships: Data from Canada

Godley \& Russell-Mayhew

Journal of Research in Interprofessional Practice and Education

Vol. 1.2

August, 2010 varied by the type of relationship. The research and talk networks had the highest percentage of same profession, whereas gather information and provide care had the lowest percentage. Respondents reported that over $60 \%$ of their working relationships occurred with people within the same type of organization. On average, respondents' research networks contained the highest percentage of ties within the same type of organization, whereas the conversational networks contained a marginally higher percentage of people from different types of organizations.

Table 3 shows the mean network size and composition measures by profession. This table provides the answer to our first research question-to what extent are those working in the field of obesity in Canada engaging in interprofessional relationships? The groups were compared using an ANOVA test on each network variable to assess the extent to which engagement in interprofessional relationships varies by profession. The $F$ statistic for each test, along with the degrees of freedom, is shown in the first column of the table.

In terms of network size, only the size of the care and the research networks differed significantly across professions. We conducted post hoc LSD tests on the care and research network size measures to look at specific group comparisons. As we would expect, psychologists and psychiatrists, medical doctors, and nurses indicated that their networks of people with whom they provide care are larger than those of the academics and those of public health workers and administrators. Academics reported larger networks of people with whom they conduct research than dietitians/nutritionists, kinesiologists, psychologists and psychiatrists, medical doctors, nurses, and public health workers.

In terms of the percent of people in respondents' networks who are from the same profession, only the networks talk to and provide care with showed significant differences across professions. Post hoc tests illustrate that nurses reported a higher proportion of their care provision networks to be of the same profession (38.92\%) than all other professions except psychologists and psychiatrists. Nurses also reported talking to a higher percentage of people from the same profession (46.91\%) than all other professions, as did academics in kinesiology (57.83\%). Administrators reported talking to a lower percentage of people in the same profession $(4.76 \%)$ than all others.

In terms of the percentage of people in respondents' networks who are from the same type of organization, again only the networks of people respondents talk to and provide care with showed significant differences across professions. Post hoc tests showed that, with the exception of social scientists, all of the academics reported that a higher percentage of those they talk to come from the same type of organization (university) than other professions. Nurses were an exception: they reported that on average $86.66 \%$ of the people they talk to come from the same type of organization, which is higher than any other profession. Nurses reported that a full $95.45 \%$ of those they provide care with come from the same type of organization, and dietitians reported that $62.22 \%$ of those they provide care with come from the same type of organization. Both are significantly higher than all other professions. 
Table 3

Network variables by profession

\begin{tabular}{|c|c|c|c|c|c|c|c|c|c|c|c|}
\hline & $\begin{array}{l}\text { Academic } \\
\text { Biomed. Sci. }\end{array}$ & $\begin{array}{l}\text { Academic } \\
\text { Kines. }\end{array}$ & $\begin{array}{l}\text { Academic } \\
\text { Public Health }\end{array}$ & $\begin{array}{l}\text { Academic } \\
\text { Social Sci. }\end{array}$ & $\begin{array}{c}\text { Dietitian / } \\
\text { Nutritionist }\end{array}$ & $\begin{array}{l}\text { Kines./ } \\
\text { PT / OT }\end{array}$ & $\begin{array}{l}\text { Psychol./ } \\
\text { Psychi. }\end{array}$ & $\begin{array}{l}\text { Medical } \\
\text { Doctor }\end{array}$ & Nurse & $\begin{array}{l}\text { Public } \\
\text { Health } \\
\text { Worker }\end{array}$ & Admin. \\
\hline Network Size & $N=8$ & $N=10$ & $N=16$ & $N=8$ & $N=16$ & $N=10$ & $N=4$ & $N=9$ & $N=15$ & $N=8$ & $N=7$ \\
\hline $\begin{array}{l}\text { Talk to } \\
\qquad F=.806(\mathrm{df}=110)\end{array}$ & $\begin{array}{c}6.25 \\
(3.370)\end{array}$ & $\begin{array}{c}5.20 \\
(3.155)\end{array}$ & $\begin{array}{c}5.31 \\
(2.845)\end{array}$ & $\begin{array}{l}5.38 \\
(2.560)\end{array}$ & $\begin{array}{l}7.00 \\
(2.530)\end{array}$ & $\begin{array}{c}5.80 \\
(3.293)\end{array}$ & $\begin{array}{c}7.50 \\
(3.00)\end{array}$ & $\begin{array}{c}4.89 \\
(2.848)\end{array}$ & $\begin{array}{c}6.67 \\
(3.063)\end{array}$ & $\begin{array}{c}5.50 \\
(3.546)\end{array}$ & $\begin{array}{c}4.86 \\
(2.193)\end{array}$ \\
\hline $\begin{array}{l}\text { Gather Information } \\
\quad F=1.180(\mathrm{df}=110)\end{array}$ & $\begin{array}{c}2.50 \\
(3.381)\end{array}$ & $\begin{array}{l}2.00 \\
(2.309)\end{array}$ & $\begin{array}{c}2.38 \\
(2.335)\end{array}$ & $\begin{array}{c}2.13 \\
(2.100)\end{array}$ & $\begin{array}{l}2.00 \\
(2.251)\end{array}$ & $\begin{array}{c}2.11 \\
(2.804)\end{array}$ & $\begin{array}{c}4.75 \\
(3.202)\end{array}$ & $\begin{array}{c}1.00 \\
(1.414)\end{array}$ & $\begin{array}{l}3.00 \\
(2.646)\end{array}$ & $\begin{array}{c}.88 \\
(2.475)\end{array}$ & $\begin{array}{c}1.29 \\
(1.976)\end{array}$ \\
\hline $\begin{array}{l}\text { Care } \\
\qquad F=3.877^{* *}(\mathrm{df}=110)\end{array}$ & $\begin{array}{l}.13 \\
(.354)\end{array}$ & $\begin{array}{l}.50 \\
(1.080)\end{array}$ & $\begin{array}{l}.31 \\
(.602)\end{array}$ & $\begin{array}{c}2.50 \\
(3.780)\end{array}$ & $\begin{array}{c}2.31 \\
(3.628)\end{array}$ & $\begin{array}{c}1.50 \\
(2.461)\end{array}$ & $\begin{array}{c}4.25 \\
(3.775)\end{array}$ & $\begin{array}{l}3.78 \\
(3.632)\end{array}$ & $\begin{array}{c}4.00 \\
(3.317)\end{array}$ & $\begin{array}{l}.13 \\
(.354)\end{array}$ & 00 \\
\hline $\begin{array}{l}\text { Research } \\
\qquad F=3.206^{* *}(\mathrm{df}=110)\end{array}$ & $\begin{array}{l}4.13 \\
(4.390)\end{array}$ & $\begin{array}{l}3.50 \\
(3.274)\end{array}$ & $\begin{array}{l}3.31 \\
(2.774)\end{array}$ & $\begin{array}{l}5.25 \\
(2.493)\end{array}$ & $\begin{array}{l}1.38 \\
(2.363)\end{array}$ & $\begin{array}{l}1.00 \\
(2.160)\end{array}$ & 00 & $\begin{array}{c}1.44 \\
(3.283)\end{array}$ & $\begin{array}{c}1.07 \\
(2.915)\end{array}$ & $\begin{array}{l}.25 \\
(.463)\end{array}$ & $\begin{array}{c}1.43 \\
(2.507)\end{array}$ \\
\hline \multicolumn{12}{|l|}{ Percent Same Profession } \\
\hline $\begin{array}{l}\text { Talk to } \\
\qquad F=3.107^{* *}(\mathrm{df}=110)\end{array}$ & $\begin{array}{c}38.99 \\
(15.22) \\
8\end{array}$ & $\begin{array}{c}57.83 \\
(29.80) \\
10\end{array}$ & $\begin{array}{l}23.12 \\
(27.06) \\
16\end{array}$ & $\begin{array}{c}30.42 \\
(38.86) \\
8\end{array}$ & $\begin{array}{c}17.97 \\
(24.43) \\
16\end{array}$ & $\begin{array}{c}16.67 \\
(19.64) \\
9\end{array}$ & $\begin{array}{c}27.08 \\
(12.94) \\
4\end{array}$ & $\begin{array}{c}27.34 \\
(27.28) \\
8\end{array}$ & $\begin{array}{c}46.91 \\
(27.95) \\
14\end{array}$ & $\begin{array}{c}41.04 \\
(43.85) \\
8\end{array}$ & $\begin{array}{c}4.76 \\
(12.60) \\
7\end{array}$ \\
\hline $\begin{array}{l}\text { Gather Information } \\
F=.637(\mathrm{df}=62)\end{array}$ & $\begin{array}{c}42.67 \\
(36.77) \\
5\end{array}$ & $\begin{array}{c}23.33 \\
(25.82) \\
6\end{array}$ & $\begin{array}{c}31.06 \\
(34.58) \\
11\end{array}$ & $\begin{array}{c}28.00 \\
(38.99) \\
5\end{array}$ & $\begin{array}{c}20.37 \\
(35.14) \\
9\end{array}$ & $\begin{array}{c}28.77 \\
(37.35) \\
6\end{array}$ & $\begin{array}{c}46.83 \\
(12.22) \\
3\end{array}$ & $\begin{array}{c}43.75 \\
(42.70) \\
4\end{array}$ & $\begin{array}{c}23.48 \\
(23.02) \\
10\end{array}$ & $\begin{array}{c}14.29 \\
i\end{array}$ & $\begin{array}{l}0 \\
0 \\
3\end{array}$ \\
\hline $\begin{array}{l}\text { Care } \\
\qquad F=3.143^{* *}(\mathrm{df}=39)\end{array}$ & $\begin{array}{l}0 \\
1\end{array}$ & $\begin{array}{l}0 \\
0 \\
2\end{array}$ & $\begin{array}{l}0 \\
0 \\
4\end{array}$ & $\begin{array}{c}3.33 \\
(5.77) \\
3\end{array}$ & $\begin{array}{c}10.19 \\
(12.66) \\
6\end{array}$ & $\begin{array}{c}35.56 \\
(17.11) \\
3\end{array}$ & $\begin{array}{c}28.89 \\
(7.70) \\
3\end{array}$ & $\begin{array}{c}27.54 \\
(37.27) \\
6\end{array}$ & $\begin{array}{c}38.92 \\
(27.63) \\
11\end{array}$ & $\begin{array}{c}100 \\
1\end{array}$ & $\dot{0}$ \\
\hline $\begin{array}{l}\text { Research } \\
\qquad F=1.556(\mathrm{df}=49)\end{array}$ & $\begin{array}{c}52.20 \\
(47.40) \\
5\end{array}$ & $\begin{array}{c}20.88 \\
(19.98) \\
7\end{array}$ & $\begin{array}{c}38.71 \\
(41.07) \\
14\end{array}$ & $\begin{array}{c}44.29 \\
(37.13) \\
8\end{array}$ & $\begin{array}{c}5 \\
(1.11) \\
5\end{array}$ & $\begin{array}{c}8.33 \\
(11.79) \\
2\end{array}$ & $\dot{0}$ & $\begin{array}{c}56.67 \\
(40.42) \\
3\end{array}$ & $\begin{array}{c}8.33 \\
(11.79) \\
2\end{array}$ & $\begin{array}{l}0 \\
0 \\
2\end{array}$ & $\begin{array}{l}0 \\
0 \\
2\end{array}$ \\
\hline \multicolumn{12}{|c|}{ Percent Same Type of Organization } \\
\hline $\begin{array}{l}\text { Talk to } \\
\qquad F=2.320^{*}(\mathrm{df}=110)\end{array}$ & $\begin{array}{c}71.13 \\
(31.76) \\
8\end{array}$ & $\begin{array}{c}70.39 \\
(25.86) \\
10\end{array}$ & $\begin{array}{c}69.27 \\
(27.92) \\
16\end{array}$ & $\begin{array}{c}43.33 \\
(25.56) \\
8\end{array}$ & $\begin{array}{c}58.17 \\
(35.61) \\
16\end{array}$ & $\begin{array}{c}57.88 \\
(37.23) \\
9\end{array}$ & $\begin{array}{c}49.58 \\
(37.57) \\
4\end{array}$ & $\begin{array}{c}61.16 \\
(45.26) \\
8\end{array}$ & $\begin{array}{c}86.66 \\
(18.95) \\
14\end{array}$ & $\begin{array}{c}38.33 \\
(34.82) \\
8\end{array}$ & $\begin{array}{c}37.41 \\
(31.30) \\
7\end{array}$ \\
\hline $\begin{array}{l}\text { Gather information } \\
F=.797(\mathrm{df}=62)\end{array}$ & $\begin{array}{c}74 \\
(43.36) \\
5\end{array}$ & $\begin{array}{c}80 \\
(40) \\
6\end{array}$ & $\begin{array}{c}66.67 \\
(37.82) \\
11 \\
11\end{array}$ & $\begin{array}{c}56 \\
(51.77) \\
5\end{array}$ & $\begin{array}{c}58.15 \\
(35.94) \\
9\end{array}$ & $\begin{array}{c}52.98 \\
(46.09) \\
6\end{array}$ & $\begin{array}{c}49.21 \\
(45) \\
3\end{array}$ & $\begin{array}{c}75 \\
(50) \\
4\end{array}$ & $\begin{array}{c}75.07 \\
(34.50) \\
10 \\
10 \ldots\end{array}$ & $\begin{array}{c}14.29 \\
i\end{array}$ & $\begin{array}{c}24.44 \\
(21.43) \\
3\end{array}$ \\
\hline $\begin{array}{l}\text { Care } \\
\qquad F=4.080^{* *}(\mathrm{df}=39)\end{array}$ & $\begin{array}{l}0 \\
1\end{array}$ & $\begin{array}{l}0 \\
0 \\
2\end{array}$ & $\begin{array}{c}37.50 \\
(47.87) \\
4\end{array}$ & $\begin{array}{c}23.33 \\
(40.42) \\
3\end{array}$ & $\begin{array}{c}79.63 \\
(40) \\
6\end{array}$ & $\begin{array}{c}100 \\
0 \\
3\end{array}$ & $\begin{array}{c}62.22 \\
(40.19) \\
3\end{array}$ & $\begin{array}{c}46.19 \\
(46.61) \\
6\end{array}$ & $\begin{array}{c}95.45 \\
(15.08) \\
11\end{array}$ & $\begin{array}{l}0 \\
i\end{array}$ & $\dot{0}$ \\
\hline $\begin{array}{l}\text { Research } \\
\qquad F=1.168(\mathrm{df}=49)\end{array}$ & $\begin{array}{c}73.56 \\
(42.12) \\
5\end{array}$ & $\begin{array}{c}76.19 \\
(30.21) \\
7\end{array}$ & $\begin{array}{c}65.53 \\
(38.87) \\
14\end{array}$ & $\begin{array}{c}75.36 \\
(21.15) \\
8\end{array}$ & $\begin{array}{c}61.67 \\
(36.13) \\
5\end{array}$ & $\begin{array}{c}25 \\
(35.36) \\
2\end{array}$ & $\dot{j}$ & $\begin{array}{c}23.33 \\
(25.17) \\
3\end{array}$ & $\begin{array}{c}78.33 \\
(16.50) \\
2\end{array}$ & $\begin{array}{c}50 \\
(70.71) \\
2\end{array}$ & $\begin{array}{c}37.50 \\
(17.68) \\
2\end{array}$ \\
\hline
\end{tabular}




\section{JRIPE}

98

Interprofessional Relationships:

Data from Canada

Godley \& Russell-Mayhew

Data from Canada
Journal of Research in Interprofessional Practice and Education

Vol. 1.2

August, 2010
Table 4

\section{Attitudes towards interprofessional practice - factor analysis}

\begin{tabular}{|c|c|c|c|c|}
\hline \multirow[b]{2}{*}{ Item } & \multicolumn{4}{|c|}{ Factor Loading } \\
\hline & I & II & III & IV \\
\hline Individuals in my profession have good relations with people in other professions. & .776 & & & \\
\hline Individuals in my profession are willing to share information and resources with other professionals. & .757 & & & \\
\hline Individuals in my profession think highly of other related professions. & .731 & & & \\
\hline $\begin{array}{l}\text { Individuals in my profession make every effort to understand the } \\
\text { capabilities and contributions of other professions. }\end{array}$ & .710 & & & \\
\hline Individuals in my profession are able to work closely with individuals in other professions. & .666 & & & \\
\hline Individuals in my profession work well with each other. & .625 & & & \\
\hline Individuals in my profession are extremely competent. & .559 & .521 & & \\
\hline Individuals in my profession are well trained. & .538 & & & \\
\hline Individuals in other professions respect the work done by my profession. & & .801 & & \\
\hline Individuals in other professions think highly of my profession. & & .794 & & \\
\hline Individuals in other professions often seek the advice of people in my profession. & & .713 & & \\
\hline Individuals in my profession have a higher status than individuals in other professions. & & .651 & & \\
\hline Individuals in my profession trust each other's professional judgment. & & .539 & & \\
\hline Individuals in my profession are very positive about their goals and objectives. & & & .891 & \\
\hline Individuals in my profession are very positive about their contributions and accomplishments. & & & .835 & \\
\hline Individuals in my profession demonstrate a great deal of autonomy. & & & & .769 \\
\hline Individuals in my profession need to cooperate with other professions. & & & & .763 \\
\hline Percent Variance Explained & 22.152 & 19.171 & 10.193 & 9.495 \\
\hline Cronbach's Alpha Coefficient & .858 & .800 & .830 & .56 \\
\hline
\end{tabular}

Note: Factor loadings less than .5 were suppressed. One of the original 18 items in the scale, Item 8 (Individuals in my profession must depend upon the work of people in other professions), did not load on any factor, thus it is excluded from this table.

\section{Attitudes}

Table 4 shows the results of the factor analysis of the 18 items in the IEP scale. We conducted the factor analysis using principal component analysis and varimax rotation. We retained component factors with eigen values greater than 1.0. Four component factors accounted for $61.01 \%$ of the variation in the scale. The four factors encompassed the following dimensions:

1. Perception of cooperation between members of one's own profession and other professions (eight items);

2. Perception that one's own profession has high status (six items);

3. Perception that members of one's own profession have a positive outlook (two items);

4. Perception that members of one's own profession need to cooperate with other professions yet usually act autonomously (two items). 
99

Interprofessional Relationships:

Data from Canada

Godley \& Russell-Mayhew
Journal of Research in Interprofessional Practice and Education

Vol. 1.2

August, 2010

Cronbach's alpha coefficients were calculated to examine the reliability of the four factors. The first three factors each had a score of .800 or higher, suggesting that all three are reliable measures (these factor scores are higher than those reported by Luecht et al. (1990) [41] in their initial usage of the IEPS). The fourth factor had a score of .562, suggesting marginal reliability. The overall internal consistency coefficient for all 18 items was .833. The factor loadings of the individual items, along with the percent of variance explained and the Cronbach's alpha coefficients, are all shown in Table 4.

\section{Attitudes by profession}

Table 5 shows the results of the ANOVA comparing the attitudinal factors across professions. This table provides the results to address our second set of research questions: What are the attitudes of those working in the field of obesity in Canada with regards to interprofessional practice? And do these attitudes vary by profession?

Most of the differences between the professions were not significant. However, it is interesting to note that medical doctors and academics in the biomedical field both

Table 5

\section{Attitudinal factor scores by profession}

\begin{tabular}{|c|c|c|c|c|c|}
\hline & & $\begin{array}{c}\text { Cooperation } \\
F=1.809\end{array}$ & $\begin{array}{l}\text { Status } \\
F=1.881\end{array}$ & $\begin{array}{l}\text { Positive } \\
F=1.281\end{array}$ & $\begin{array}{l}\text { Autonomy } \\
F=1.974^{*}\end{array}$ \\
\hline $\begin{array}{l}\text { Academic } \\
\text { Biomed. } \\
\text { Sci. }\end{array}$ & $N=7$ & $\begin{array}{c}-.490 \\
(1.080)\end{array}$ & $\begin{array}{c}.922 \\
(.907)\end{array}$ & $\begin{array}{l}.510 \\
(.490)\end{array}$ & $\begin{array}{c}.365 \\
(.735)\end{array}$ \\
\hline $\begin{array}{l}\text { Academic } \\
\text { Kines. }\end{array}$ & $N=8$ & $\begin{array}{l}.137 \\
(1.245)\end{array}$ & $\begin{array}{l}-.314 \\
(.908)\end{array}$ & $\begin{array}{l}-.216 \\
(.982)\end{array}$ & $\begin{array}{c}-.961 \\
(1.319)\end{array}$ \\
\hline $\begin{array}{c}\text { Academic } \\
\text { Public } \\
\text { Health }\end{array}$ & $N=15$ & $\begin{array}{l}-.118 \\
(.926)\end{array}$ & $\begin{array}{l}.077 \\
(.911)\end{array}$ & $\begin{array}{c}-.418 \\
(1.322)\end{array}$ & $\begin{array}{c}.542 \\
(.875)\end{array}$ \\
\hline $\begin{array}{l}\text { Academic } \\
\text { Social Sci. }\end{array}$ & $N=8$ & $\begin{array}{c}.378 \\
(1.033)\end{array}$ & $\begin{array}{l}-.099 \\
(.606)\end{array}$ & $\begin{array}{l}.393 \\
(.696)\end{array}$ & $\begin{array}{l}-.092 \\
(.798)\end{array}$ \\
\hline $\begin{array}{r}\text { Dietitian/ } \\
\text { Nutritionist: }\end{array}$ & $N=11$ & $\begin{array}{l}.069 \\
(.971)\end{array}$ & $\begin{array}{c}-.410 \\
(1.424)\end{array}$ & $\begin{array}{c}-.194 \\
(1.325)\end{array}$ & $\begin{array}{l}-.180 \\
(.757)\end{array}$ \\
\hline $\begin{array}{l}\text { Kines./ } \\
\text { PT / OT }\end{array}$ & $N=8$ & $\begin{array}{l}.503 \\
(.516)\end{array}$ & $\begin{array}{c}-.001 \\
(1.114)\end{array}$ & $\begin{array}{c}-.411 \\
(1.091)\end{array}$ & $\begin{array}{c}.445 \\
(.686)\end{array}$ \\
\hline $\begin{array}{l}\text { Psychol./ } \\
\text { Psychi. }\end{array}$ & $N=2$ & $\begin{array}{l}.076 \\
(.793)\end{array}$ & $\begin{array}{c}.228 \\
(1.351)\end{array}$ & $\begin{array}{c}.553 \\
(1.134)\end{array}$ & $\begin{array}{c}.516 \\
(1.699)\end{array}$ \\
\hline $\begin{array}{l}\text { Medical } \\
\text { Doctor }\end{array}$ & $N=8$ & $\begin{array}{l}-.912 \\
(.852)\end{array}$ & $\begin{array}{l}.812 \\
(.711)\end{array}$ & $\begin{array}{l}.126 \\
(.509)\end{array}$ & $\begin{array}{l}-.136 \\
(.728)\end{array}$ \\
\hline Nurse & $N=12$ & $\begin{array}{c}.562 \\
(.654)\end{array}$ & $\begin{array}{l}-.105 \\
(.639)\end{array}$ & $\begin{array}{c}.328 \\
(.717)\end{array}$ & $\begin{array}{c}.090 \\
(1.105)\end{array}$ \\
\hline $\begin{array}{l}\text { Public } \\
\text { Health } \\
\text { Worker }\end{array}$ & $N=7$ & $\begin{array}{c}-.428 \\
(1.032)\end{array}$ & $\begin{array}{c}-.577 \\
(1.011)\end{array}$ & $\begin{array}{l}.423 \\
(.920)\end{array}$ & $\begin{array}{c}-.529 \\
(1.304)\end{array}$ \\
\hline Admin. & $N=4$ & $\begin{array}{c}-.079 \\
(1.479)\end{array}$ & $\begin{array}{l}-.360 \\
(.722)\end{array}$ & $\begin{array}{l}-.574 \\
(.516)\end{array}$ & $\begin{array}{l}-.285 \\
(.671)\end{array}$ \\
\hline
\end{tabular}

Notes:1. Cells contain Mean, (Standard Deviation);

2. For F-statistic $\mathrm{df}=89$; * significant at $\mathrm{p}<.05$ scored lowest on the first factor (perception of cooperation between members of one's own profession and other professions) and highest on the second factor (perception that one's own profession has high status).

The only factor to show significant differences between professions was the "autonomy but need to cooperate with other professions" factor. We conducted a post hoc LSD test to examine the group comparisons and found that on average, academic kinesiologists were lower (-.961) and academic public health professionals were higher (.542) on this factor than individuals in other professions. These results should be interpreted with caution, though, as this factor had marginal reliability (see above). 
Interprofessional Relationships: Data from Canada

Godley \& Russell-Mayhew

Journal of Research in Interprofessional Practice and Education

Vol. 1.2

August, 2010

\section{Journal of Research in Interprofessional Practice and Education}

\section{Network variables and attitudes}

To answer our third research question-How are attitudes toward interprofessional practice related to self-reported actual interprofessional relationships? - we next examined the relationship between the network variables and the attitudinal factors. We ran bivariate correlations between each of the network variables (network size, percent same profession, and percent same type of organization) for all four types of relationships with the four attitudinal variables. In the whole sample, we found no significant correlations (at $p<.01$ ) between the scores on the attitudinal factors and the network variables. We looked for correlations between the network variables and the attitudinal factors by profession, and also found no significant correlations ${ }^{1}$.

\section{Type of work}

Finally, we examined the relationship between the type of work individuals reported (clinical, research, or a mix of clinical and research) and the network and attitudinal variables. This analysis provided the answer to our fourth research question-Is the type of work an individual does correlated with either their engagement in interprofessional relations or their attitudes toward interprofessional practice?

First, we examined type of work by profession to ensure that we were not confounding type of work and profession. We found that in every profession except psychology/psychiatry (where all respondents reported doing only clinical work), respondents reported doing at least two types of work, and in five of the professions respondents reported doing all three types of work. Thus we feel confident that type of work and profession are not coterminous.

Table 6 shows the results of the comparison of the network variables across type of work. F-test results for the ANOVA are included in the first column. Network size differed significantly across type of work for the talk, care and research relationships. The percent same profession in the talk and research networks differed across type of work, and the percent same organization in the care networks differed across type of work.

The post hoc LSD showed the following significant group differences. Respondents who reported doing clinical and research work talk to more people (6.87), on average, than respondents who reported doing just research (5.12). Respondents in both the clinical only and the clinical and research groups reported more people in their care networks (3.00 and 2.47) than did respondents in the research only group (0.30). And respondents in both the research only and the clinical and research groups reported more people in their research networks (3.51, 2.80) than did respondents in the clinical only group (0.03).

Respondents in the research only group had higher percentages of people from the same profession in their talk networks (37.70) and in their research networks (39.20) than respondents who do both clinical and research work. And respondents in the research only group reported lower proportions of their care network coming from the same type of organization (14.29) than respondents in the clinical or clinical and research groups.

We next examined the mean attitudinal factor scores by type of work, using 
101

Interprofessional Relationships:

Data from Canada

Godley \& Russell-Mayhew
Journal of Research in Interprofessional Practice and Education

Vol. 1.2

August, 2010
Table 6

Network measures by type of work

\begin{tabular}{|c|c|c|c|}
\hline & $\begin{array}{l}\text { Clinical } \\
\text { Only }\end{array}$ & $\begin{array}{l}\text { Research } \\
\text { Only }\end{array}$ & $\begin{array}{l}\text { Clinical and } \\
\text { Research }\end{array}$ \\
\hline Network Size & $N=36$ & $N=43$ & $N=30$ \\
\hline $\begin{array}{l}\text { Talk to } \\
\qquad F=.3 .326^{*}(\mathrm{df}=108)\end{array}$ & $\begin{array}{c}5.78 \\
(3.034)\end{array}$ & $\begin{array}{c}5.12 \\
(2.692)\end{array}$ & $\begin{array}{c}6.87 \\
(2.862)\end{array}$ \\
\hline $\begin{array}{l}\text { Gather Information } \\
\quad F=.180(\mathrm{df}=108)\end{array}$ & $\begin{array}{c}2.31 \\
(2.584)\end{array}$ & $\begin{array}{l}2.00 \\
(2.449)\end{array}$ & $\begin{array}{c}2.28 \\
(2.419)\end{array}$ \\
\hline $\begin{array}{l}\text { Care } \\
\quad F=11.203^{* *}(\mathrm{df}=107)\end{array}$ & $\begin{array}{c}3.00 \\
(3.207)\end{array}$ & $\begin{array}{l}.300 \\
(.914)\end{array}$ & $\begin{array}{c}2.47 \\
(3.569)\end{array}$ \\
\hline $\begin{array}{l}\text { Research } \\
\qquad F=18.216^{* *}(\mathrm{df}=108)\end{array}$ & $\begin{array}{l}.03 \\
(.167)\end{array}$ & $\begin{array}{c}3.51 \\
(3.165)\end{array}$ & $\begin{array}{c}2.80 \\
(3.316)\end{array}$ \\
\hline \multicolumn{4}{|l|}{$\begin{array}{l}\text { Percent Same } \\
\text { Profession }\end{array}$} \\
\hline $\begin{array}{l}\text { Talk to } \\
\qquad F=3.938^{*}(\mathrm{df}=105)\end{array}$ & $\begin{array}{c}32.80 \\
(29.20) \\
34\end{array}$ & $\begin{array}{c}37.70 \\
(33.10) \\
43\end{array}$ & $\begin{array}{c}18.60 \\
(19.90) \\
29\end{array}$ \\
\hline $\begin{array}{l}\text { Gather Information } \\
\quad F=1.535(\mathrm{df}=62)\end{array}$ & $\begin{array}{c}33.40 \\
(31.30) \\
21\end{array}$ & $\begin{array}{c}31.00 \\
(33.90) \\
24\end{array}$ & $\begin{array}{c}17.10 \\
(26.60) \\
18\end{array}$ \\
\hline $\begin{array}{l}\text { Care } \\
\qquad F=1.550(\mathrm{df}=39)\end{array}$ & $\begin{array}{c}31.67 \\
(27.06) \\
20\end{array}$ & $\begin{array}{c}14.29 \\
(37.80) \\
7\end{array}$ & $\begin{array}{c}17.26 \\
(23.22) \\
13\end{array}$ \\
\hline $\begin{array}{l}\text { Research } \\
\qquad F=6.713^{* *}(\mathrm{df}=49)\end{array}$ & i & $\begin{array}{c}39.20 \\
(38.27) \\
32\end{array}$ & $\begin{array}{c}10.43 \\
(15.75) \\
17\end{array}$ \\
\hline \multicolumn{4}{|l|}{$\begin{array}{l}\text { Percent Same Type of } \\
\text { Organization }\end{array}$} \\
\hline $\begin{array}{l}\text { Talk to } \\
\qquad F=2.588(\mathrm{df}=105)\end{array}$ & $\begin{array}{c}72.48 \\
(33.69) \\
34\end{array}$ & $\begin{array}{c}60.09 \\
(30.54) \\
43\end{array}$ & $\begin{array}{c}54.51 \\
(34.09) \\
29\end{array}$ \\
\hline $\begin{array}{l}\text { Gather information } \\
\quad F=1.535(\mathrm{df}=62)\end{array}$ & $\begin{array}{c}69.76 \\
(39.14) \\
21\end{array}$ & $\begin{array}{c}67.99 \\
(37.96) \\
24\end{array}$ & $\begin{array}{c}49.66 \\
(41.40) \\
18\end{array}$ \\
\hline $\begin{array}{l}\text { Care } \\
\qquad F=7.519^{* *}(\mathrm{df}=39)\end{array}$ & $\begin{array}{c}79.69 \\
(35.24) \\
20\end{array}$ & $\begin{array}{c}14.29 \\
(37.80) \\
7\end{array}$ & $\begin{array}{c}62.91 \\
(43.21) \\
13\end{array}$ \\
\hline $\begin{array}{l}\text { Research } \\
\qquad F=2.717(\mathrm{df}=49)\end{array}$ & $\dot{i}$ & $\begin{array}{c}69.85 \\
(34.03) \\
32\end{array}$ & $\begin{array}{c}55.65 \\
(34.63) \\
17\end{array}$ \\
\hline
\end{tabular}

Notes: 1. Network Size Cells contain Mean, (Standard Deviation)

2. Network Composition Cells contain Mean, (Std. Dev.), N;

3. ${ }^{* *}$ indicates $F$ is significant at $p<.01$;

${ }^{*}$ indicates $F$ is significant at $p<.05$
ANOVA. There were no significant differences between the mean attitudinal scores by type of work ${ }^{2}$.

\section{Discussion and conclusions}

Our results provide a unique assessment of the actual working relationships and attitudes toward interprofessional practice of professionals engaged in obesity management and prevention in Canada. We saw that, on average, these professionals talk to approximately six other people about obesity-related issues, whereas they gather information, provide care, and conduct research with approximately two other people. As we would expect based on job descriptions of the various professions, the size of the care and research networks varied by profession. Psychologists and psychiatrists, medical doctors, and nurses have larger networks of people with whom they provide care than members of other professions, whereas academics have larger networks of people with whom they conduct research.

It is clear from our data that there are already a significant number of interprofessional relationships in the field of obesity. On average, respondents reported that approximately $75 \%$ of the people they work with are from other professions. Care provision was the most interprofessional, with respondents reporting that $76.06 \%$ of those with whom they provide care come from other professions. Research was the least diverse, yet respondents still reported that $70.36 \%$ of those with whom they conduct research come from other professions. The type of organization an individual works in appears to be more important than profession in determining working arrangements. Over $60 \%$ of respondents' working relationships occurred within the same type of organization, whereas only $25-30 \%$ occurred with members of the same profession.

Although we examined individuals from eleven different health professions, we 
102

Interprofessional Relationships: Data from Canada

Godley \& Russell-Mayhew

Journal of Research in Interprofessional Practice and Education

Vol. 1.2

August, 2010 found very few professional differences in interprofessional relationships. The only relationships to show differences across professions were talk to and provide care with. Academic kinesiologists reported the lowest levels of interprofessional relationships in terms of discussion networks: $42.17 \%$ of those they talk to are from a different profession. Administrators reported the highest level of interprofessional relationships in their discussion networks: over $95 \%$ of those they talk to are from a different profession.

Nurses reported that $46.91 \%$ of those they talk to are from the same profession, and $38.92 \%$ of those they provide care with are from the same profession; these figures are significantly higher than those for all the other professions except the academic kinesiologists. Nurses are also most likely to report that the people they talk to and provide care with are from the same type of organization (a hospital or healthcare setting). Speculating as to why nurses may engage in fewer interprofessional relationships than other healthcare professionals, it may have to do with the fact that they are primarily involved in patient care, usually working closely with other nurses to cover their patients' needs 24 hours a day.

Although we found differences between professions in the composition of the discussion and care networks, we did not find differences in the gathering information and conducting research networks. For the current analysis, we examined the four different relationships as separate networks, yet the relationships may not be mutually exclusive. In future research, we plan to experiment with collapsing the four networks into different relationships categories (for example, collapsing talk to, gathering information, and conducting research into one network and contrasting it with the providing care network) to see if our results change when we compare different categories of interprofessional relationships.

Thus the conclusion to our first set of research questions-To what extent are those working in the field of obesity in Canada engaging in interprofessional relationships? Does the extent of engagement in interprofessional relationships vary by profession?-is that in the field of obesity, at least in the limited sample of professionals we analyzed, the importance of interprofessional relations has been recognized [3,5]. In particular, we see that professionals working to provide care to those suffering from the effects of obesity are working with other professionals to improve patient outcomes [8]. We should remind readers, however, that our findings may be biased by our recruitment method. Our sample is not representative of all professionals who work in the obesity field, or even of all attendants at the CON Summit. Because we recruited respondents at the CON meeting (which was explicitly interprofessional), they may be more likely to engage in interprofessional relationships (and have more favourable attitudes toward interprofessional practice) than all people who work in the obesity field.

Our second set of research questions was: What are the attitudes of those working in the field of obesity in Canada with regards to interprofessional practice? Do these attitudes vary by profession? Analyzing the data on attitudes toward interprofessional practice, we found that four factors accounted for differences in attitudes in our sample. These factors were: perception of cooperation between members of 
103

Interprofessional Relationships: Data from Canada

Godley \& Russell-Mayhew

Journal of Research in Interprofessional Practice and Education

Vol. 1.2

August, 2010 one's own profession and other professions; perception that one's own profession has high status; perception that members of one's own profession have a positive outlook; and perception that members of one's own profession usually act autonomously yet need to cooperate with other professions.

The only attitudinal factor that showed significant variation by profession was the last one, with academic kinesiologists scoring lowest and academic public health professionals scoring highest on the perception that the members of their own profession usually acted autonomously yet needed to cooperate with other professionals. It is interesting to note that academic kinesiologists also had the lowest levels of interprofessional contact within their discussion networks. While academic kinesiologists do not see themselves as autonomous, they also do not believe that they need to cooperate with other professions, and this attitude is borne out in practice. On the other hand, compared with other professions, academic public health professionals perceive themselves as autonomous but feel that they do need to cooperate with other professions.

Our third research question asked: How are attitudes toward interprofessional practice related to self-reported actual interprofessional relationships? Interestingly, we found no correlation between attitudes toward interprofessional practice and actual interprofessional relationships. None of the attitudinal factors correlated with the network variables. We speculate that if we had analyzed individuals within each profession separately, we may have found a relationship between attitudes toward interprofessional practice and actual relationships. However, we do not have enough respondents in each professional category to do these analyses. A future study, with a larger sample size, could investigate the relationship between attitudes and relationships within profession.

Thus we conclude that attitudes toward interprofessional practice in our sample of professionals working in the field of obesity are generally positive, do not vary by profession (except that academic kinesiologists do not feel the need to cooperate with other professions and academic public health specialists do feel the need to cooperate with other professions), and are not related to actual interprofessional relationships. Our findings are supported by previous qualitative research that demonstrated a positive attitude toward interprofessional practice by members of several professions in the field of obesity [51].

Our final research question was: Is the type of work an individual does (clinical, research, or a mix of the two) correlated with either the extent of their involvement in interprofessional relationships or their attitudes toward interprofessional practice? We examined the network and attitudinal variables by the respondents' type of work. Network size differed across type of work for all but the gather information networks. Those who do both clinical and research work talk to more people on average than those who do just research. Not surprisingly, respondents in clinical and clinical and research have larger care networks than those who reported doing research only, and respondents in research and research and clinical have larger research networks than those who reported doing clinical work. Overall, we can conclude that those engaged in both clinical and research work had the largest networks in the sample. 
Interprofessional Relationships: Data from Canada

Godley \& Russell-Mayhew
Journal of Research in Interprofessional Practice and Education

Vol. 1.2

August, 2010

\section{Journal of Research in Interprofessional Practice and Education}

The network composition of the respondents' discussion and research networks also varied by type of work. Those who reported doing only research had the least diverse networks, whereas those who reported doing both clinical and research work had the highest percentage of interprofessional contacts in their discussion and research networks. The scores on the attitudinal factors did not vary by type of work. Thus we conclude that professionals engaged in both clinical and research work in the field of obesity have the largest networks and the most contact with professionals from other fields.

To summarize, using ego-centred social network analysis to quantify the working relationships of professionals in the field of obesity, we found that interprofessional relationships were very common, particularly among those engaged in both clinical and research work. We found that attitudes toward interprofessional practice were generally positive, and did not vary by profession or by type of work. Future research could use social network analysis to examine interprofessional relationships in other areas of chronic disease management, such as diabetes and cardiovascular disease. Additionally, future research could also use network analytic tools to assess the impact of interprofessional relationships on patient outcomes.

\section{Acknowledgements}

We would like to acknowledge the assistance of Tara Bond and Danielle Gabert in administering the survey at the CON Summit.

\section{Notes}

1. These results are not shown but are available from the authors upon request.

2. Results available from authors upon request.

\section{References}

1. Baldwin, D.C. (2007). Some historical notes on interdisciplinary and interprofessional education and practice in health care in the USA. Journal of Interprofessional Care, 21(S1), 23-37.

2. Courturier, Y., Gagnon, D., Carrier, S., \& Etheridge, F. (2008). The interdisciplinary condition of work in relational professions of the health and social care field: A theoretical perspective. Journal of Interprofessional Care, 22, 341-351.

3. Leathard, A. (2003). Interprofessional collaboration: From policy to practice in health and social care. New York: Brunner-Routledge.

4. Paul, S., \& Peterson, C.Q. (2001). Interprofessional collaboration: Issues for practice and research. Occupational Therapy in Health Care, 15, 1-12.

5. Smith, R., \& Anderson, L. (2008). Interprofessional Learning: Aspiration or Achievement? Social Work Education, 27, 759-776.

6. Snyder, R.C. (2001). A societal backdrop for interprofessional education and practice. Theory Into Practice, 26, 94-98.

7. Kemp, K.A.R. (2007). The use of interdisciplinary medical teams to improve quality and access to care. Journal of Interprofessional Care, 21, 557-559.

8. Nancarrow, S.A., \& Borthwick, A.M. (2005). Dynamic professional boundaries in the healthcare workforce. Sociology of Health and Illness, 897-919.

9. Cyphert, F.R., \& Cunningham, L.L. (2001). Interprofessional education and practice: A future agenda. Theory Into Practice, 26, 153-156.

10. D’Amour, D., Ferrada-Videla, M., Rodriguez, L.S.M., \& Beaulieu, M.D., (2005). The conceptual basis for interprofessional collaboration: Core concepts and theoretical frameworks. Journal of Interprofessional Care, S-1, 116-131. 
105

Interprofessional Relationships:

Data from Canada

Godley \& Russell-Mayhew

Journal of Research in Interprofessional Practice and Education

Vol. 1.2

August, 2010
11. Martin, G.P., Currie, G., \& Finn, R. (2009). Reconfiguring or reproducing intra-professional boundaries? Specialist expertise, generalist knowledge and the 'modernization' of the medical workforce. Social Science and Medicine, 68, 1191-1198.

12. Giacomini, M. (2004). Interdisciplinarity in health services research: Dreams and nightmares, maladies and remedies. Journal of Health Services Research \& Policy, 9, 177-183.

13. Hudson, B. (2002). Interprofessionality in health and social care: The Achilles' heel of partnership? Journal of Interprofessional Care, 16, 7-17.

14. Cava, M. (2008). Is public health ready for a professional practice framework? Journal of Health Service Research Policy, 13(S1), 57-63.

15. Garman, A.N., Leah, D.C., \& Spector, N. (2006). Worldviews in collision: Conflict and collaboration across professional lines. Journal of Organizational Behaviour, 27, 829-849.

16. Reynolds, J. (2007). Discourses of inter-professionalism. British Journal of Social Work, 37, 441-457.

17. Hall, P. (2005). Interprofessional teamwork: Professional cultures as barriers. Journal of Interprofessional Care, 19, 188-196.

18. Pecukonis, E., Doyle, O., \& Bliss, D.L. (2008). Reducing barriers to interprofessional training: Promoting interprofessional cultural competence. Journal of Interprofessional Care, 22, 417-428.

19. Centre for the Advancement of Interprofessional Education. (1997). Interprofessional education: A definition for health and social care. London: CAIPE Report.

20. Reeves, S., Zwarenstein, M., Goldman, J., Barr, H., Freeth, D., Hammick, M. \& Koppel, I. (2009). Interprofessional education: Effects on interprofessional practice and health care outcomes (Review). Cochrane Review, 4, 1-22.

21. D’Amour, D., Ferrada-Videla, M., Rodriguez, L.S.M., \& Beaulieu, M.D., \& Oandasan, I. (2005). Interprofessionality as the field of interprofessional practice and interprofessional education: An emerging concept. Journal of Interprofessional Care, 19, 8-20.

22. Kessel, F. \& Rosenfield, P.L. (2008). Toward transdisciplinary research: Historical and contemporary perspectives. American Journal of Preventive Medicine, 35(S2), S225-S234.

23. Rosenfield, P.L. (1992). The potential of transdisciplinary research for sustaining and extending linkages between the health and social sciences. Social Science and Medicine, 35, 1343-1357.

24. Scott, C.M., \& Hofmeyer, A.T. (2007). Acknowledging complexity: Critically analyzing context to understand interdisciplinary research. Journal of Interprofessional Care, 21, 491-501.

25. Easen, P., Atkins, M., \& Dyson, A. (2000). Inter-professional collaboration and conceptualisations of practice. Children and Society, 14, 355-367.

26. Salhani, D., \& Charles, G. (2007). The dynamics of an interprofessional team: The interplay of child and youth care with other professions within a residential treatment milieu. Relational Child and Youth Care Practice, 20, 12-20.

27. Salhani, D., Charles, G.. \& Coulter, I. (2009). The politics of interprofessional working and the struggle for professional autonomy in nursing. Social Science and Medicine, 68, 1221-1228.

28. Baxter, S.K., \& Brumfitt, S.M. (2008). Professional differences in interprofessional working. Journal of Interprofessional Care, 22, 239-251.

29. Stevens, F.C.J., Diedericks, J.P.M., Grit, F. \& van der Horst, F. (2007). Exclusive, idiosyncratic and collective expertise in the interprofessional arena: The case of optometry and eye care in The Netherlands. Sociology of Health and Illness, 29, 481-496.

30. Lewis, J.M., Baeza, J.I., \& Alexander, D. (2008). Partnerships in primary care in Australia: Network structure, dynamics and sustainability. Social Science and Medicine, 67, 280-291.

31. Martin-Rodriguez, L.S., Beaulieu, M.-D., D’Amour, D., \& Ferrada-Videla, M. (2005). The determinants of successful collaboration: A review of theoretical and empirical studies. Journal of Interprofessional Care, 19, 132-147.

32. Sargeant, J., Loney, E., \& Murphy, G. (2008). Effective interprofessional teams: "Contact is not enough" to build a team. Journal of Continuing Education in the Health Professions, 28, 228-234.

33. Anderson, E.S., \& Thorpe, L.N. (2008) Early interprofessional interactions: Does student age matter? Journal of Interprofessional Care, 22, 263-282.

34. Shia, N., \& Clarke, J. (2008). Bringing down the Berlin Wall in academia. Journal of Interprofessional Care, 22, 213-215.

35. Cooper, H., \& Geyer, R. (2008). Using 'complexity' for improving educational research in health care. Social Science and Medicine, 67, 177-182.

36. Willison, K.D. (2008). Advancing integrative medicine through interprofessional education. Health Sociology Review, 17, 342-352.

37. Blickem, C., \& Privadharshini, E. (2007). Patient narratives: The potential for 'patient-centred' interprofessional learning? Journal of Interprofessional Care, 21, 619-632. 
JRIPE

106

Interprofessional Relationships:

Data from Canada

Godley \& Russell-Mayhew
38. Hutton, E., \& Coxon, K. (2008). Involving patients as service users in an interprofessional research project. Journal of Interprofessional Care, 22, 661-663.

39. Thannhauser, J., Russell-Mayhew, S., \& Scott, C. (2010). Measures of interprofessional education and collaboration. Jourrnal of Interprofessional Care, 24(4), 336-349.

40. Parsell, G., \& Bligh, J. (1999). The development of a questionnaire to assess the readiness of health care students for interprofessional learning (RIPLS). Medical Education, 33(2), 95-100. research project. Journal of Interprofessional Care, 22, 661-663.

41. Luecht, R.M., Madsen, M.K., Taugher, M.P., \& Petterson, B.J. (1990). Assessing professional perceptions. Design and validation of an interdisciplinary education perception scale. Journal of Allied Health, 19, 181-191.

42. Suter, E., Arndt, J., Arthur, N., Parboosingh, J., Taylor, E. \& Deutschlander, S. (2009). Role understanding and effective communication as core competencies for collaborative practice. Journal of Interprofessional Care, 23, 41-51.

43. Wellman, B. (1988). "Structural analysis: from method and metaphor to theory and substance." In Wellman, B. and Berkowitz, S.D. Social Structure: A network approach. Greenwich, CT: JAI Press.

44. Scott, J. (2000). Social Network Analysis: a handbook, $2^{\text {nd }}$ ed. London: Sage.

45. Wasserman, S., \& Faust, K. (1994). Social network analysis: Methods and applications. Cambridge: Cambridge University Press.

46. Tjepkema, M., \& Shields M. (2005). Measured obesity: Adult obesity in Canada. In Nutrition: Findings from the Canadian Community Health Survey, Issue No. 1. (Catalogue No. 82-620MWE). Ottawa, ON: Statistics Canada.

47. Katzmarzyk, P.T. (2002). The Canadian obesity epidemic, 1985-1998. CMAJ, 166(8), 1039-1040.

48. Wyatt, S., Winters, K. \& Dubbert, P. (2006). Overweight and obesity: Prevalence, consequences, and causes of a growing public health problem. The American Journal of the Medical Sciences, 331, 166-174.

49. Lau, D.C.W., Douketis, J.D., Morrison, K.M., Hramjak, I.M., Sharma, A.M., \& Ur, E. (2007). 2006 Canadian clinical practice guidelines on the management and prevention of obesity in adults and children. CMAJ, 176, S1-S117.

50. Baillargeon, J.-P., Carpentier, A., Donovan, D., Fortin, M., Grant, A., Simoneau-Roy, J., St. Cyr Tribble, D., Xhignesse, M., \& Langlois, M.-F. (2007). Integrated obesity care management system - implementation and research protocol. BMC Health Services Research, 7. Doi: 10.1186/1472-62963-7-163.

51. Russell-Mayhew, S., Scott, C., \& Stewart, M. (2008). The Canadian Obesity Network and interprofessional practice: Members 'views. Journal of Interprofessional Care, 22, 149-165.

52. Vehovar, V., Manfreda, K.L., Koren, G., \& Hlebec, V. (2008). Measuring ego-centred social networks on the web: Questionnaire design issues. Social Networks, 30, 213-222.

53. Freeman, L.C. (2004). The development of social network analysis: A study in the sociology of science. Vancouver, BC: Empirical Press.

54. McFadyen, A., Maclaren, W., \& Webster, V. (2007). The Interdisciplinary Education Perception Scale (IEPS): An alternative remodelled sub-scale structure and its reliability. Journal of Interprofessional Care, 21, 433-443.
Journal of Research in Interprofessional Practice and Education

Vol. 1.2

August, 2010 


\section{JRIPE}

107

Interprofessional Relationships:

Data from Canada

Godley \& Russell-Mayhew
Journal of Research in Interprofessional Practice and Education

\section{Appendix A \\ Online Questionnaire: \\ Attitudes towards Interprofessional Practice}

The following questions ask about your impressions of interprofessional practice. Please indicate the degree to which you agree or disagree with each statement. (Response Options: Strongly Disagree; Disagree; Not sure; Agree; Strongly Agree)

1. Individuals in my profession are well-trained.

2. Individuals in my profession are able to work closely with individuals in other professions.

3. Individuals in my profession demonstrate a great deal of autonomy.

4. Individuals in other professions respect the work done by my profession.

5. Individuals in my profession are very positive about their goals and objectives.

6. Individuals in my profession need to cooperate with other professions.

7. Individuals in my profession are very positive about their contributions and accomplishments.

8. Individuals in my profession must depend upon the work of people in other professions.

9. Individuals in other professions think highly of my profession.

10. Individuals in my profession trust each other's professional judgment.

11. Individuals in my profession have a higher status than individuals in other professions.

12. Individuals in my profession make every effort to understand the capabilities and contributions of other professions.

13. Individuals in my profession are extremely competent.

14. Individuals in my profession are willing to share information and resources with other professionals.

15. Individuals in my profession have good relations with people in other professions.

16. Individuals in my profession think highly of other related professions.

17. Individuals in my profession work well with each other.

18. Individuals in other professions often seek the advice of people in my profession.
Journal of Research in Interprofessional Practice and Education

Vol. 1.2

August, 2010 


\section{JRIPE}

108

Interprofessional Relationships: Data from Canada

Godley \& Russell-Mayhew

\section{Appendix B}

List of professions provided in the online questionnaire:

Academic - Biomedical Scientist

Academic - Kinesiologist

Academic - Natural Scientist

Academic - Public Health / Community Health

Academic - Social Scientist

Academic - Other

Biomedical Scientist (non-academic)

Dietitian

Kinesiologist (non-academic)

Medical Doctor - Psychiatrist

Medical Doctor - Surgeon

Medical Doctor - Other

Natural Scientist (non-academic)

Nurse

Nutritionist

Occupational Therapist

Pharmacist

Physiotherapist

Psychologist

Public Health / Community Health practitioner (non-academic)

Social Scientist (non-academic)

Social Worker

Student (Students were then asked to provide their discipline and their degree program)

Teacher / Educator

Other (please specify) 